\title{
Combined Heat and Power (CHP) studies at the Flint Bio-Gas Complex Using a 1.4 MW Direct Fuel Cell - A Demonstration Study.
}

\author{
${ }^{1}$ Etim U. Ubong, ${ }^{2}$ Uwem Ubong, ${ }^{1}$ Vipul Laddha, ${ }^{1}$ Pouyan Pourmovahed \\ ${ }^{1}$ Mechanical Engineering Department \\ Center for Fuel Cell Research \& Powertrain Integration \\ 1700 University Ave, Flint, MI USA. \\ Phone/Fax number:+1-810- 762-7436, e-mail: eubong@kettering.edu; \\ ladd3387@kettering.edu; pour3112@kettering.edu \\ ${ }^{2}$ Department of Environmental Chemistry, Akwa Ibom University of Technology, A'Ibom State \\ Uyo, Nigeria \\ e-mail: uwembassey@yahoo.com
}

\begin{abstract}
Future energy systems should include distributed power generation with combined heat and power. A study is conducted to evaluate the economic competitiveness of using a high temperature fuel cell with combined heat and power as a distributed power generation system against the conventional grid supplied power system at a sewage treatment facility. This report evaluates the economic benefits of using natural gas or biogas from the sewage treatment plant at the Flint-Biogas Complex to power a $1.4 \mathrm{MW}$ direct fuel cell which operates at a temperature of $400{ }^{\circ} \mathrm{C}$. The waste recovery heat will be used for heating the sludge and the facility. Bottoming cycle options are proposed. The waste heat will be used to warm the sludge, heat up the reactants and provide warm water throughout the facility. This approach eliminates or reduces additional energy cost. The most important engineering and economic indicators would be used for evaluating the CHP system against the conventional furnace and power from the grid.
\end{abstract}

\section{Key words}

Combined Heat and Power, Direct Fuel cell, Stationary power system, Sewage treatment plant, Conventional heating system, Economic analysis.

\section{Introduction}

One of the main advantages of the direct fuel cell system is that the main power plant is located close to the utility. Combined heat and power advocates the use of waste heat for cogeneration. Combined heat and power (CHP) is an economical way of generating electricity with one primary power system -(the FC) and utilizing the waste heat to generate yet more power using turbo-expander, steam or gas turbine and using the recovered heat for heating purposes. This reduces the number of equipment in the balance of plant. This principle finds a wide application in distributed power set ups with the obvious advantages of high efficiency, elimination of a network of complex power grid and the losses associated with it, which results in cost reduction [1]. The recovered heat finds a wide application in heating swimming pools, greenhouses, space heating and hot water systems in high rise buildings.

The goal of this work is to use methane or bio-fuel from the waste treatment plant in Flint for fueling the fuel cell and the recovered heat for cogeneration. The gas separation and processing units will be powered by a high temperature fuel cell based on Molten Carbonate fuel cell (MCFC) and the heat will be used in the facilities in the waste treatment plant. This principle is energy efficient.

\section{Literature Review}

Bio-gas is a product of anaerobic digestion of organic wastes such as municipal waste, sewage, farm manure, domestic organic products, etc. A typical composition of biogas from a waste treatment plant or landfill are methane: $(50-75 \%)$, carbon dioxide $(25-50 \%)$, Nitrogen (0-10), hydrogen sulfide (0-3\%) and hydrogen (0-1\%. $/ 2 /$. There are trace elements of the other gases in the landfill gases' composition and that includes particulate matter. But the raw fuel has to be purified first using known technologies such as separation by membrane, etc., before use in a FC.

The presence of hydrogen sulfide in the composition raises concerns about the life of the equipment. It is imperative to remove the sulfide containing compounds. Many approaches are adopted to purify the raw gas such as using water washing technique in which cascading counter-flow water stream is used against high pressure gas flow direction to scrub the gas. Biogas composition is a function of the source material. The waste gases can then be separated to obtain methane. A U.S. DOE study 
ten years ago showed that $4.31 \times 10^{10} \mathrm{kWh}$ of energy from landfill gas was used, which constituted $0.6 \%$ of the amount of natural gas used in the United States /3/.

A Sankey diagram (not shown here for brevity reasons) of the direct fuel cell with CHP based on the high temperature fuel cell proposed for this project shows that the FC has a $47 \%$ efficiency and the bottoming cycle $18 \%$. That is $65 \%$ efficiency from electricity production. An estimated $25 \pm 2 \%$ waste heat use is expected for various heating requirements in the waste treatment plant. That brings up the efficiency to $90 \pm 2 \%$. The remaining $10 \%$ non-recoverable waste heat will account for losses and fuel utilization efficiency from a reformate. Since the waste treatment plant (WTP) is located is a cold región (Michigan, USA) with temperature dipping to $-20{ }^{\circ} \mathrm{C}$ during winter time, part of the waste heat will be used for space heating, hot water, and process analysis at the waste treatment plant. The final result shows an estimated 90$92 \%$ efficiency use of the input energy.

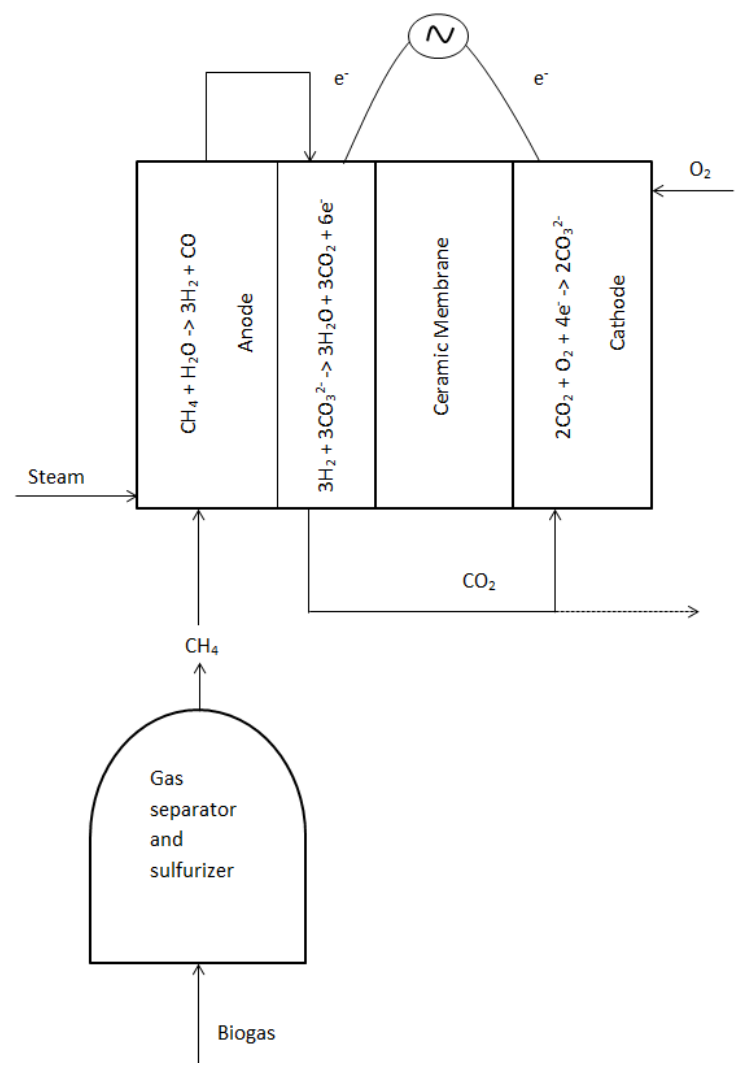

Figure 1. Indirect Internal reformation in a high temperature fuel cell.

The main source of energy for the WTP has always been electricity from the grid and natural gas bought from the Consumer Energy- the energy suppliers. The proposed model using MCFC proposes capitalizing on the FC heat for most of its heat requirement and minimizing fuel gas use, with its high seasonal cost.

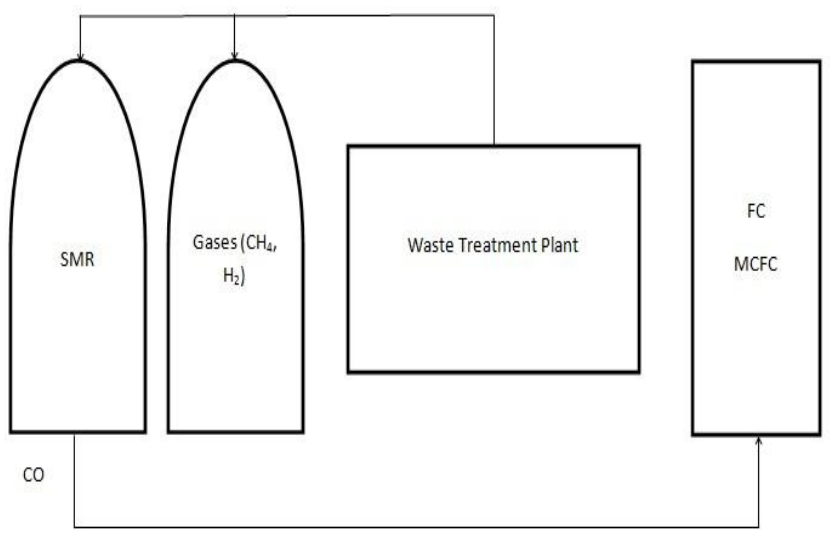

Figure 2. Indirect internal reformation of bio-fuel in medium temperature fuel cells.

The use of biogas presents a set of problems especially for medium temperature fuel cells, such as high temperature proton exchange fuel cells based on polybenzimidazole (PBI) membranes. In such cases, an externally steam reformation process is adopted such as shown in Figure 2 to produce hydrogen. The power and heat from the fuel cell is then used for other heating requirements, thereby eliminating heat from a conventional furnace that burns additional fuel.

\section{Process Analysis}

Processing and use of biogas from the landfill or waste treatment plant is more involved than using natural gas from the oil well. The hydrogen sulfide (a by-product of the anaerobic digestion) or fermentation of organic material must first be scrubbed. Sulfide removal from the gas stream of the biogas also applies to natural gas from the fossil source. This is followed by gas separation notably the membrane separation technique. The reaction of natural gas in an indirect internal reformation to generate electricity is shown in Figure 1.

A desulfurized $\mathrm{CNG}$ is fed into a separated (noncatalyst) anode chamber of MCFC at around $400{ }^{\circ} \mathrm{C}$ where it reacts with steam to form hydrogen and carbon monoxide. The products are re-routed into the anode catalyst chamber where the hydrogen reacts with mobile carbonate ion from the cathode to form steam, carbon dioxide and electrons. The electrons go through the external circuit to generate direct electricity.

The carbon dioxide is re-routed into the cathode where it combines with oxygen and the electrons from the external circuit to produce a mobile carbonate ion, $\mathrm{CO}_{3}{ }^{-2}$. The exhaust heat from both the anode and cathode find a wide application in bottoming cycle in a turbo expander to cogenerate further electricity. Turbo-expander is regarded as an indispensible bottoming cycle especially where a large workforce is concerned. The noise level is very low. 
The reactions at the anode using hydrogen as fuel are as follows:

Anode: $2 \mathrm{H}_{2}+2 \mathrm{CO}_{3}^{2-} \rightarrow 2 \mathrm{H}_{2} \mathrm{O}+2 \mathrm{CO}_{2}+4 e^{-}$

Cathode: $\mathrm{O}_{2}+2 \mathrm{CO}_{2}+4 e^{-} \rightarrow 2 \mathrm{CO}_{3}^{2-}$

MCFC can also use carbon monoxide as fuel in an internal reformation process.

Anode reaction:

$2 \mathrm{CO}+2 \mathrm{CO}_{3}^{2-}->4 \mathrm{CO}_{2}+4 e^{-}$

At the cathode:

Cathode: $\mathrm{O}_{2}+2 \mathrm{CO}_{2}+4 e^{-} \rightarrow 2 \mathrm{CO}_{3}^{2-}$

Using methane a component of biogas as fuel, the reaction takes the form:

At the anode:

$\mathrm{CH}_{4}+\mathrm{H}_{2} \mathrm{O} \rightarrow 3 \mathrm{H}_{2}+\mathrm{CO}$

This process proceeds as above in the first divided (noncatalyst) chamber of the anode. In the catalytic anode chamber, the process proceeds as follows:

$$
2 \mathrm{H}_{2}+2 \mathrm{CO}_{3}^{2-} \rightarrow 2 \mathrm{H}_{2} \mathrm{O}+2 \mathrm{CO}_{2}+4 e^{-}
$$

At the cathode

Cathode: $\mathrm{O}_{2}+2 \mathrm{CO}_{2}+4 e^{-} \rightarrow 2 \mathrm{CO}_{3}^{2-}$

In above processes, nickel is used as a catalyst at the anode and nickel oxide at the cathode. The membrane is a ceramic matrix containing lithium and sodium carbonate or a mixture of lithium or potassium /3/.

\section{Economic analysis and performance}

A complete month by month cost of using energy from the grid will is used for comparative analysis with the FC power with CHP. The FC system can run on multiple fuels including landfill gases or natural gas from the municipal waste treatment plant. The exhaust heat from the fuel cell will support process analysis in the waste treatment plant.

The economic benefits are geared towards improving energy efficiency and reducing environmental pollution. There are obviously other technical issues and regulatory issues to be addressed. The interconnectivity issues are a hurdle to link the CHP to the grid and the issue can take various forms such as technical hardware for easy connectivity. Equipment for easy connectivity/disconnectivity is not readily available as stock items, as such, constitutes a big hurdle. One great concern is the grid -power provider's policy and readiness to allow distributed power to be fed into the grid. Safety issues arise. What if the grid power is down and the electricians unaware of the fact that power from the nearby distributed plant is on and the worker is electrocuted? Hence, there are still some unresolved issues about distributed power connection to the grid, which calls for a standard.

Some technical question to be addressed are: What are the most possible energy combinations with MCFC factoring in cost effectiveness, air quality, noise level and ease of harnessing? Some considerations are:

* MCFC with turbo expander with the use of waste heat for heating (swimming pool, hot water system for the dormitories, space heating, greenhouse houses temperature control, etc.

* Using hydraulic compressed hot air to produce mechanical power.

* Using gas or steam turbine

The rationale behind distributed power generation is to bring the power system closer to the user. The topping cycle (MCFC) has to be clean so also the bottoming cycle. The noise level from the topping and bottoming cycles should be within acceptable levels. Due to difficulties in information sharing and dissemination, actual data from the Waste Treatment Plant (WTP) from their monthly utility bills will not be presented here. However, available information will be used for decisións reached in this work. Table 1 presents advantages of the proposed FC for the project while Tables 2 and 3 below present the financial information of the project model.

Table 1. Technical Specification of the proposed FC Model suitable for the project /1/

\begin{tabular}{|c|c|c|}
\hline Technical Specifcation of DFC 1500 & & English unit \\
\hline Power output @plant rating & $1.4 \mathrm{MW}$ & \\
\hline Output Voltage & $480 \mathrm{~V}$ & \\
\hline Efficiency (LHV) & $47 \%$ & \\
\hline Exhaust flow & & $18,300 \mathrm{lb} / \mathrm{h}$ \\
\hline Available recoverable heat energy & & $2,216,000 \mathrm{Btu} / \mathrm{h}$ \\
\hline Fuel consumption & & $181 \mathrm{scfm}$ \\
\hline Sound level & \multicolumn{2}{|c|}{$72 \mathrm{db}(\mathrm{A})$ at $10 \mathrm{ft}$} \\
\hline \multicolumn{3}{|l|}{ Emissions } \\
\hline Nox & & $0.01 \mathrm{lb} / \mathrm{MWh}$ \\
\hline SOx & & $10^{-4} \mathrm{lb} / \mathrm{MWh}$ \\
\hline PM - particulate matter & & $2 \times 10^{-5} \mathrm{lb} / \mathrm{MWh}$ \\
\hline \multicolumn{3}{|l|}{ Greenhouse Gas } \\
\hline $\mathrm{CO}_{2}$ & & $980 \mathrm{lb} / \mathrm{MWh}$ \\
\hline $\mathrm{CO}_{2}$ with waste heat recovery & & $520-680 \mathrm{lb} / \mathrm{MWh}$ \\
\hline
\end{tabular}


Table 2. Fuel Cell Cost Statement [4-6]

\begin{tabular}{lc}
\hline $\begin{array}{l}\text { Fuel Cell System Costs }- \text { Fixed } \\
\text { Cost per year }\end{array}$ & USD \\
\hline $\begin{array}{l}\text { Capital Costs of 1.4MW Fuel Cell } \\
\text { system }\end{array}$ & 900,712 \\
Installation Costs & 295,933 \\
$\begin{array}{l}\text { Commissioning Costs (Start-up, Testing, } \\
\text { Tutorials for Operators) }\end{array}$ & 29,593 \\
Shipping & 59,186 \\
$\begin{array}{l}\text { Payments } \\
\text { Fuel Cell System Incentives }\end{array}$ & 516,000 \\
$\begin{array}{l}\text { Self-generation Incentive } \\
\text { (SGIP) at } \$ 2500 / k W e\end{array}$ & 616,528 \\
$\begin{array}{l}\text { Federal Investment Tax Credit } \\
\text { at \$3000/kWe }\end{array}$ & 318,128 \\
Total Yearly Fixed Costs & 773,916 \\
\hline
\end{tabular}

Table 3. FCS Operating Data /4-6/

\begin{tabular}{lcc}
\hline Fuel Cell System Operating Data & Quantity & Units \\
\hline Maximum Electrical Output & 1400 & $\mathrm{~kW}$ \\
\hline Minimum Electrical Output & - & $\mathrm{kW}$ \\
Maximum Heat-to-Electric Power Ratio & 0.9 & BTU of natural gas $/ \mathrm{kWh}$ \\
of recovered heat
\end{tabular}




\section{Discussion of the Economic model}

The discussion of the merits will follow a complete analysis of the operational cost of electricity, heating and cooling. The work done by /4-6/ compares CHP with the conventional power generation and concludes that both fuel and $\mathrm{CO}_{2}$ emissions are reduced by $46 \%$ when $\mathrm{CHP}$ is used instead of the conventional power plant. A $1.4 \mathrm{MW}$ power unit based on MCFC featured in Table 1 above justifies the use of the CHP based on emissions levels output by the power plant. The consumption of 181 standard cubic feet/minute $(\mathrm{scfm})-(\mathrm{a}$ cubic $\mathrm{ft}=$ 28.32liter) of methane from the biogas treatment plant justifies the use of the CHP for project. This eliminates the cost of fuel gas used in furnaces and protects the environment.

A onetime cost of setting up the plant and elimination of the monthly utility bill for electricity and fuel gas (CNG) for furnaces upset the bill. A $30 \%$ federal incentive for those using renewable energy significantly lowers the cost of acquisition of the MCFC plant. This is shown in Table 2. Both natural gas and hydrogen will be produced from the plant for mass transit buses and hydrogen for hydrogen powered vehicles. These bring in revenue to upset any cost. Table 2 and 3 give a summary of the cost of acquiring the unit. A comparison of the electricity bill and fuel gas bill shows a $40 \%$ advantage of MCFC with bottoming cycle over the current conventional power system at the WTP. Emissions from the MCFC are unmatchable to that of the conventional system as see from Table 1.

\section{Conclusions}

The engineering community is gradually experiencing a shift in various methods of energy production from the fossil fuel sources with combustion engines. The colossal impact of environmental pollution calls for novel power generation practices without releasing pollutants resulting from combustion (nitrogen oxides- NOx, oxides of sulfurSOx, hydrocarbons- $\mathrm{HCs}$, particulates and $\mathrm{CO}_{2}$ ) into the atmosphere. Extracting heat from these power plants and bottoming cycles further reduce the fuel and maintenance cost of boilers for various heating needs. Most importantly, placing the power System near the site of application reduces the cost of complex network of power lines. The power line transmission losses are also minimized.

\section{References}

[1]. www.fuelcellenergy.com/technology.php

[2]. http://en.wikipedia.org/wiki/Biofuel

[3]. J.Larmine and A. Dicks. Fuel Cell Explained. John Wiley \& Sons, New York, 2000.

[4]. Whitney G. Colella, Viraj Srivastava. Examining the Integration of Fuel Cell Systems into Building Through Simulation. Proceedings of the ASME $201210^{\text {th }}$ Fuel Cell Science Engineering \& Technology Conference. FuelCell2012. July 23-26, 2012, San Diego, CA, USA. Paper - FuelCell2012-91474.

[5].Whitney G. Colella. Optimal Design and Control Strategies for Novel Combined heat and Power (CHP) Fuel Cell Systems: Part I of II - Datum Design Conditions and Approach. Proceedings of the ASME 2012 6th International Conference on Energy SustainabilityES2010

[6]. Whitney G. Colella, Sandia National Labs. Optimizing operation of stationary fuel cell systems (FCS) within district cooling and heating networks. Proceedings of the ASME $20126^{\text {th }}$ International Conference on Energy Sustainability, Paper ES201033134. 